\title{
EVALUASI PENERAPAN PENATAUSAHAAN BARANG MILIK DAERAH PADA BPK-BMD KABUPATEN MINAHASA UTARA
}

\author{
Lucky Jansen Manurung $^{1}$, Jullie J. Sondakh ${ }^{2}$, Novi S. Budiarso ${ }^{3}$ \\ ${ }^{1,2,3}$ Jurusan Akuntansi, Fakultas Ekonomi dan Bisnis, Universitas Sam Ratulangi, J1. Kampus Bahu, Manado, \\ 95115, Indonesia
}

E-mail : yansenmanurung95@gmail.com

\begin{abstract}
Regional-Owned Assets Administration (BMD) by Badan Pengelola Keuangan dan Barang Milik Daerah (BPK-BMD) Kabupaten Minahasa Utara conducted by following Permendagri No. 19 Tahun 2016 about Technical guideline of Regional-Owned Assets in thus recording, inventory, and reporting processes of Regional-Owned Assets in this government region is showed well, is resulting regional balance sheet basic for BPK-BMD Kabupaten Minahasa Utara. This research's objective is to figure out whether the implementation of RegionalOwned Assets Administration in BPK-BMD Kabupaten Minahasa Utara has been followed Permendagri Nomor 19 Tahun 2016 and its' research type is descriptive analysis. This research outcome has concluded that Regional-Owned Assets in Kabupaten Minahasa Utara Government has been conducted by following Permendagri Nomor 19 Tahun 2016. BPKBMD Kabupaten Minahasa Utara in implementing Regional-Owned Assets Administration, is based on the existed Permendagri Nomor 19 Tahun 2016 and Regional-Owned Users and Authorized Parties keep maintain this procedurs in Kabupaten Minahasa Utara.
\end{abstract}

Keywords : Regional Owned Assets Management, Controlling and Monitoring.

\section{PENDAHULUAN}

Laporan pertanggung jawaban harus "memperhatikan setiap aspek yang akan dilaporkan dalam laporan pertanggungjawaban. Pemerintah juga harus memeriksa kembali penatausahaan aset barang milik daerah apakah sudah sesuai dengan peraturan perundangundangan atau tidak. Terkadang masyarakat kurang memperhatikan apa saja yang menjadi Barang Milik Daerah (aset) yang ada di daerah masing-masing dan apakah Barang Milik Daerah tersebut sudah digunakan dan dimanfaatkan oleh pemerintah dengan baik. Pendayagunaan Barang Milik Daerah (BMD) yang pastinya tidak sama dari setiap instansi di Kabupaten Minahasa Utara membuat penatausahaan Barang Milik Daerah yang dimiliki dan dikelola oleh pihak pemerintah kabupaten ini tidak sesederhana itu, tanpa meniadakan kinerja yang baik dalam setiap proses penatausahaan. Sistem penatausahaan Barang Milik Daerah di kabupaten ini masih juga mempergunakan sumber daya manusia dan fasilitas yang telah ada sebelumnya, sehingga ada kemungkinan pengecekan dalam sistem tersebut. Untuk mengetahui bagaimana Penerapan Penatausahaan Aset/Barang Milik Daerah Kabupaten Minahasa Utara telah terselenggara dengan baik sesuai dengan Peraturan Pemerintah Dalam Negeri Nomor 19 Tahun 2016.

\section{TINJAUAN PUSTAKA}

Akuntansi. Libby (2009) dalam Pontoh (2013 : 8) mendefinisikan "akuntansi adalah sebuah sistem informasi yang dirancang oleh sebuah organisasi untuk mengidentifikasi (analisis, mencatat, dan meringkas) aktivitas-aktivitas yang mempengaruhi kondisi dan kinerja keuangannya, kemudian mengkomunikasikan hasilnya kepada pengambil keputusan, baik dari internal maupun eksternal organisasi." 
Standar Akuntansi Pemerintahan. Standar Akuntansi Pemerintahan "yaitu pemerintah pusat, pemerintah daerah, dan satuan organisasi di lingkungan pemerintah pusat/daerah. Dalam peraturan perundang-undangan satuan organisasi wajib menyajikan laporan keuangan. Dengan demikian, Standar Akuntansi Pemerintahan menjadi satu-satunya standar pelaksanaan akuntansi pemerintah sehingga upaya pengharmonisasian berbagai peraturan di pemerintah pusat dan daerah dengan Standar Akuntansi Pemerintahan mutlak dilakukan”.

Sistem Akuntansi Pemerintahan. Berdasarkan Peraturan Menteri Keuangan PP 71 Tahun 2010 adalah "rangkaian sistematik dari prosedur, penyelenggara, peralatan, dan elemen lain untuk mewujudkan fungsi akuntansi sejak analisis transaksi sampai dengan pelaporan keuangan di lingkungan pemerintah."

\section{Aset Tetap}

Pengertian Aset Tetap. Dalam Standar Akuntansi Pemerintahan (PSAP) Nomor 7 "menjelaskan bahwa Aset Tetap adalah aset yang berwujud fisik yang dapat dilihat keberadaanya dan sifatnya relatif permanen yang memiliki masa manfaat lebih dari 12 bulan untuk digunakan dalam kegiatan pemerintahan oleh masyarakat umum."

\section{Barang Milik Daerah}

Pengertian Barang Milik Daerah. Berdasarkan Permendagri Nomor 17 Tahun 2007, "Barang Milik Daerah adalah semua kekayaan daerah baik yang dibeli atau diperoleh atas beban Anggaran Pendapatan dan Belanja Daerah maupun yang berasal dari perolehan lain yang sah baik yang bergerak maupun tidak bergerak beserta bagian yang merupakan satuan tertentu yang dapat dinilai, dihitung, diukur atau ditimbang termasuk hewan dan tumbuhtumbuhan kecuali uang dan surat berharga lainnya."

Penatausahaan Barang Milik Daerah. Permendagri Nomor 19 Tahun 2016 menjelaskan bahwa "Proses Penatausahaan adalah kegiatan yang meliputi pembukuan, inventaris dan pelaporan barang milik daerah sesuai dengan ketentuan yang berlaku."

Penelitian Terdahulu. Sihombing (2016) "Tujuan dari penelitian ini adalah mengidentifikasi penyebab pengelolaan aset yang belum maksimal, menganalisis sistem dan pengendalian serta faktor yang mempengaruhi kinerja aparatur pengelola aset dan merumuskan strategi peningkatan kinerja aparatur pengelola asset." Kolinug (2015) Fakhrudin (2016) "Tujuan penelitian ini adalah untuk mengetahui efektivitas penatausahaan aset tetap dalam proses pembukuan, inventarisasi dan pelaporan sesuai dengan prosedur yang terdapat di dalam Permendagri no 17 tahun 2007 dan untuk mengetahui permasalahan yang terjadi di dalam prosedur pembukuan, inventarisasi serta pelaporan sesuai dengan Permendagri no 17 tahun 2007." Sari (2012) "Penelitian ini memfokuskan pada pengelolaan peralatan khusus yang meliputi perencanaan dan penganggaran, pengadaan, penggunaan, pemindahtanganan, penatausahaan, serta pembinaan, pengawasan dan pengendalian."

\section{METODE PENELITIAN}

Jenis Penelitian. Penelitian ini menggunakan jenis penelitian deskriptif kualitatif. Husein Umar, (2013 : 34) menyatakan bahwa penelitian deskriptif memiliki alternatif tujuan antara lain untuk mengetahui pelaksanaan suatu aturan. Jadi data yang diperoleh serta dukungan literatur lainnya kemudian menguraikan secara rinci dengan cara mendeskripsikan secara langsung dan digunakan sebagai dasar untuk membuat keputusan-keputusan. Serta membandingkan dengan Peraturan Menteri Dalam Negeri RI Nomor 19 Tahun 2016.

Tempat dan Waktu Penelitian. Yang menjadi tempat penelitian penulis adalah "Badan Pengelola Keuangan dan Barang Milik Daerah Kabupaten Minahasa Utara. Yang beralamat di Jalan SBY Airmadidi Minahasa Utara." 
Prosedur Penelitian. Prosedur yang digunakan yaitu "permohonan mengadakan penelitian, pengumpulan data, pengolahan data, pengambilan kesimpulan, pemberian saran"

\section{Metode Pengumpulan Data}

Jenis Data. Jenis data yang digunakan dalam penelitian ini yaitu "data kualitatif dimana data fisik dan data dokumenter, berupa gambaran umum Badan Pengelola Keuangan dan Barang Milik daerah Kabupaten Minahasa Utara dan data mengenai Barang Milik daerah Kabupaten Minahasa Utara.

Sumber Data. Sumber data yang digunakan penulis dalam penelitian ini adalah "dalam bentuk data primer yang merupakan data asli yang diperoleh langsung dari objek penelitian pada Badan Pengelola Keuangan dan Barang Milik Daerah Kabupaten Minahasa Utara. Dan sumber data primer yang diambil berupa Struktur Organisasi, Visi dan Misi BPK-BMD, Kartu Inventaris Barang, Kartu Inventaris Ruangan.

\section{Teknik Pengumpulan Data}

Wawancara. Penelitian ini menggunakan "kuesioner yang disebarkan kepada seluruh manajer/kepala bagian di Rumah Sakit Umum Daerah Sukawesi Utara.”

Studi Kepustakaan. Metode pengumpulan data yang penulis gunakan yaitu "dengan cara mempelajari literatur-literatur dan sumber-sumber tertulis lainnya yang berhubungan dengan masalah yang akan diteliti dalam penulisan ini termasuk jurnal-jurnal sebelumnya baik nasional maupun internasional.

Metode Analisa Data. Penelitian menggunakan "metode analisis deskriptif dimana metode ini dimulai dari pengidentifikasian proses penatausahaan Barang Milik Daerah. Selanjutnya data yang diperoleh dari Barang Milik daerah pada BPK-BMD Kabupaten Minahasa Utara dengan mengevaluasi penatausahaan BMD yang terdiri dari pencatatan, inventarisasi, pelaporan. Kemudian hasil yang didapat akan dibandingkan dengan teori Permendagri Nomor 19 Tahun 2016 sehingga dapat ditarik kesimpulan untuk menjawab rumusan masalah dalam penelitian ini.

\section{HASIL PENELITIAN DAN PEMBAHASAN}

Penatausahaan Barang Milik Daerah (BMD) Kabupaten Minahasa Utara. Penatausahaan Barang Milik Daerah (BMD) yang dimiliki oleh Kabupaten Minahasa Utara "sudah bersesuaian dengan Peraturan Menteri Dalam Negeri Nomor 19 Tahun 2016 yang menunjukkan bahwa setiap barang milik daerah yang dipakai dalam pemberian pelayanan publik kepada masyarakat di daerah ini telah dicatat, diteliti bagaimana pengunaan dan kondisinya, dan dilaporkan kepada pemerintah daerah dengan seksama.

Pembukuan Barang Milik Daerah (BMD) Kabupaten Minahasa Utara. Pelaksanaan pembukuan "telah mengikuti ketetapan dalam Permendagri Nomor 19 Tahun 2016 menandakan bahwa pimpinan dan semua staf di badan pemerintah daerah ini telah mempunyai kemampuan dalam mencatat setiap aset milik daerah di kabupaten ini dengan baik ke dalam semua Kartu Inventaris Barang (KIB) untuk semua Barang Milik Daerah (BMD) yang dimiliki Kabupaten Minahasa Utara dan menjadi data dalam inventarisasi dan pelaporan Barang Milik Daerah (BMD) pada laporan keuangan Kabupaten Minahasa Utara.

Inventarisasi Barang Milik Daerah (BMD) Kabupaten Minahasa Utara. Pelaksanaan inventarisasi "telah mengikuti ketetapan dalam Peraturan Menteri Dalam Negeri (Permendagri) No. 19 Tahun 2016 yang menunjukkan bahwa Badan Pengelola Keuangan dan Barang Milik Daerah (BPK-BMD) Kabupaten Minahasa Utara sudah mampu untuk memberikan informasi yang tepat mengenai bagaimana setiap barang milik daerah dipergunakan dan bagaimana penilaian yang tepat mengenai kondisi dari setiap aset milik 
daerah tersebut dalam pemberian pelayanan publik kepada masyarakat, baik secara fisik dan secara administratif.

Pelaporan Barang Milik Daerah (BMD) Kabupaten Minahasa Utara. Pelaksanaan pelaporan "telah mengikuti ketetapan dalam Permendagri Nomor 19 Tahun 2016 yang merupakan penanda bahwa pihak pimpinan dan semua staf sudah mampu membuat laporan mengenai semua aset milik daerah di kabupaten ini dan memberikan kontribusi penting dalam penyusunan laporan keuangan daerah Kabupaten Minahasa Utara.

\section{KESIMPULAN DAN SARAN}

\subsection{Kesimpulan}

Penatausahaan yang mencakup "pembukuan, inventarisasi dan pelaporan Barang Milik Daerah (BMD) di Pemerintah Kabupaten Minahasa Utara telah dilaksanakan sesuai dengan Permendagri Nomor 19 Tahun 2016 tentang Pedoman Teknis Pengelolaan Barang Milik Daerah.

\subsection{Saran}

Pengguna Barang Milik Negara dan Kuasa Pengguna Barang Milik Daerah (BMD) "harus tetap mempertahankan prosedur penatausahaan Barang Milik Daerah (BMD) di Kabupaten Minahasa Utara, mulai dari proses pembukuan, inventarisasi sampai dengan pelaporan Barang Milik Daerah (BMD) pada kabupaten ini menurut Permendagri Nomor 19 Tahun 2016."

\section{DAFTAR PUSTAKA}

Hariadi, Pramono, Restianto, Yanar E., Bawono, Icuk Rangga. 2010. Pengelolaan Keuangan Daerah. Salemba Empat. Jakarta.

Hery. 2014. Akuntansi Aset, Liabilitas, dan Ekuitas. Penerbit PT. Gramedia Widiasarana Indonesia. Jakarta.

Kusen, Gaby Jelly. 2015. Prinsip-Prinsip Hukum Pengelolaan Aset Daerah (Studi pada Pemerintah Provinsi Sulawesi Utara). Lex et Societatis, Vol. III/No. 2/Mar/2015/Edisi Khusus, Program Pascasarjana Universitas Sam Ratulangi, Manado.

Le Thi Nha Trang. 2012. Application of IPSAS Standards to the Vietnamese Government Accounting and Financial Statements. Thesis. Master Program, Public Finance Management, University Of Tampere.

Makagansa, Evita., Sondakh, Jullie J. 2015. Evaluasi Sistem Dan Ptosedur Akuntansi Aset Tetap Pada Dinas Pendidikan Pemuda Dan Olahraga Kabupaten Kepulauan Sangihe. Jurnal Berkala Ilmiah Efisiensi Vol. 15 No. 3. Tahun 2015

Mardiasmo. 2009. Akuntansi Sektor Publik. Andi. Yogyakarta

M. Yusuf. 2013. Langkah Pengelolaan Aset Daerah, Menuju Pengelolaan Keuangan Daerah Terbaik. Salemba Empat. Jakarta.

Nordiawan, Deddi dan Hertianti, Ayuningtyas. 2010. Akuntansi Sektor Publik. Salemba Empat. Jakarta

Peraturan Menteri Dalam Negeri Nomor 13 Tahun 2006 Tentang Pedoman Pengelolaan Keuangan Daerah

Peraturan Menteri Dalam Negeri Nomor 17 Tahun 2007 Tentang Pedoman Teknis Pengelolaan Barang Milik Daerah

Pesik, Patris Andreas. 2015. Evaluasi Sistem Pembinaan, Pengawasan Dan Pengendalian Barang Milik Daerah Pada BPK-BMD Kota Bitung. Jurnal EMBA 13, Vol.3 No.4 Desember 2015, Hal. 13-22, Universitas Sam Ratulangi, Manado

Pontoh, Winston. 2013. Akuntansi : Konsep dan Aplikasi. Halaman Moeka. Jakarta Barat 